\author{
Konrad Kolegowicz ${ }^{*}$
}

\title{
TENDENCJE ZMIAN WIELKOŚCI I KIERUNKÓW DZIAŁALNOŚCI GOSPODARCZEJ DUŻYCH PRZEDSIĘBIORSTW W POLSCE W LATACH 1998-2011
}

\section{WPROWADZENIE}

Jedną z najbardziej dostrzeganych cech polskiej gospodarki w okresie zapoczątkowanym zmianą ustroju politycznego, społecznego i gospodarczego od 1990 r. jest nieustannie zmieniająca się dynamika rozwoju poszczególnych dziedzin gospodarki powodująca dużą zmienność struktur gospodarczych i wzrost stopnia ich zróżnicowania. Analizy i oceny zmian wielkości i struktury działalności gospodarczej przedsiębiorstw dokonywana była i jest w różny sposób. Dlatego wyniki takich analiz i ocen mają różną wartość poznawczą i aplikacyjną. Celem większości takich analiz i ocen jest weryfikacja ogólnych prawidłowości zmian strukturalnych charakteryzujących rozwój przedsiębiorstw. Na ich podstawie potwierdza się, neguje lub koryguje zgodność rzeczywistych zmian analizowanych struktur z ogólnymi prawidłowościami zmian strukturalnych opisanych $\mathrm{w}$ literaturze ekonomicznej. Rzadziej przedmiotem analiz i ocen zmian wielkości i struktury działalności gospodarczej są współzależności między dynamiką zmian strukturalnych, a efektywnością, innowacyjnością i nowoczesnością struktur, których one dotyczą oraz zależnościami pomiędzy wyodrębnionymi w trakcie badań rodzajami struktur ${ }^{1}$.

Duża dynamika i zmienność struktur gospodarczych jest charakterystyczna dla tych spośród nich, które wyróżniają się pod względem charakteryzującej je

\footnotetext{
* Dr inż., Adiunkt, Katedra Ekonomiki i Organizacji Przedsiębiorstw, Uniwersytet Ekonomiczny w Krakowie.

${ }^{1}$ Pogląd taki zaprezentowano w pracy: S. Ku z n e t s, Wzrost gospodarczy narodów, produkt i struktura produkcji, PWN, Warszawa 1976.
} 
dynamiki rozwoju². W Polsce za taką strukturę powszechnie uznaje się zbiorowość dużych przedsiębiorstw. Przedsiębiorstwa te wyróżniają się nie tylko pod względem wielkości uzyskiwanych przychodów ze sprzedaży wytwarzanych przez nie wyrobów i usług, czy liczby osób pracujących, co stanowi kryterium ich kwalifikacji do dużych przedsiębiorstw w Polsce, ale także pod względem dynamiki tych przychodów oraz kilku innych wielkości będących charakterystykami ilościowymi ich rozwoju. Jest to zbiór przedsiębiorstw wielce zróżnicowanych pod względem cech ważnych dla charakterystyki rozwoju sektora przedsiębiorstw w gospodarce narodowej Polski, który jak wiadomo ma znaczący wpływ na stan gospodarki narodowej. Dlatego, wspomniane przedsiębiorstwa dla poznania tego stanu, stanowią interesujący obiekt badań3 ${ }^{3}$.

Pomiar kierunków zmian wielkości działalności gospodarczej ma głównie na celu określenie bezwzględnych i względnych różnic między udziałami poszczególnych składników struktury oraz sumarycznego efektu takich zmian w porównywanych momentach czasu tego samego lub wielu różnych obiektów. Poza tym chodzi w nim zazwyczaj o wskazanie kierunków przekształceń strukturalnych, obliczenie dynamiki (intensywności) zmian strukturalnych, wskazanie tych składników struktur, które w największym stopniu intensyfikują przemiany strukturalne. Na podstawie obliczeń mierników intensywności zmian strukturalnych można bardziej jednoznacznie i całościowo, niż przy pomocy tradycyjnego porównania wartości poszczególnych wskaźników struktury w czasie, ocenić stopień przekształcenia analizowanych struktur uwzględniając zmiany wartości wskaźników struktury odnoszących się do wszystkich jej składników ${ }^{4}$.

Ze względu na znaczący udział wspomnianych dużych przedsiębiorstw w gospodarce narodowej Polski interesująca jest odpowiedź na pytanie:

Czy i jak duża jest dynamika i jakie sq kierunki zmian liczby pracujacych, wartości środków trwatych, nakładów inwestycyjnych i przychodów ze sprzedaży kształtujacych i charakteryzujacych rozwój tych przedsiębiorstw?

Próba odpowiedzi na tak postawione pytania stanowi treść pracy zawierającej wyniki badań nad kierunkami i tendencjami przekształceń strukturalnych w dużych przedsiębiorstwach w Polsce po 1998 r.

\footnotetext{
${ }^{2}$ Przesłanki wyodrębniania warunków oraz czynników rozwoju gospodarczego, szczegółową ich charakterystykę i znaczenie $w$ analizie i ocenie rozwoju gospodarczego na przykładzie przemysłu przedstawiono w pracy: S. Chomątowski, Rozwój przemystu w świecie, Akademia Ekonomiczna w Krakowie, Kraków 1986, s. 12 i nast.

${ }^{3}$ Por.: S. Cho mąt ow ski (red.), Dynamika i kierunki zmian wielkości i struktury sektora przedsiębiorstw w Polsce w latach 1990-2005, Uniwersytet Ekonomiczny w Krakowie - Fundacja Uniwersytetu Ekonomicznego w Krakowie, Kraków 2010; P. Krzemiński, Zmiany liczby i struktury jednostek gospodarczych w Polsce w latach 1991-2007, [w:] Prace z zakresu ekonomiki i organizacji przedsiębiorstw, ZN UEK, $\mathrm{Nr}$ 836, Uniwersytet Ekonomiczny w Krakowie, Kraków 2010, s. 179-194.
}

${ }^{4}$ B. W in i ar s ki, Polityka gospodarcza, Wydawnictwo Naukowe PWN, Warszawa, 2006. 


\section{DYNAMIKA PRZEKSZTAŁCEŃ STRUKTURY LICZBY PRACUJĄCYCH, WARTOŚCI ŚRODKÓW TRWAŁYCH, NAKŁADÓW INWESTYCYJNYCH I PRZYCHODÓW ZE SPRZEDAŻY DUŻYCH PRZEDSIĘBIORSTW W POLSCE}

Grupą podmiotów, które poddane zostały analizie były przedsiębiorstwa duże. Obiektami analizy były zatem podmioty gospodarcze zakwalifikowane przez GUS do grupy przedsiębiorstw niefinansowych, zatrudniające ponad 249 osób. Do analizy zmian wielkości, dynamiki oraz struktury zmian dużych podmiotów gospodarczych wybrano, podobnie jak w przypadku małych i średnich przedsiębiorstw, cztery mierniki wielkości przedsiębiorstw. Do mierników tych zaliczono pracujących, wartość środków trwałych, nakłady inwestycyjne oraz wielkość przychodów ze sprzedaży. Każdy z mierników zaprezentowano w podziale na rodzaj (sekcje PKD) prowadzonej działalności gospodarczej w okresie od 1998 r. do 2011 r. W związku z wprowadzoną zmianą klasyfikacji PKD w 2007 r. zakres informacji dotyczących każdej z analizowanych mierników przedstawiono w dwóch następujących po sobie tabelach. Pierwsza z nich prezentuje analize w okresie od 1998 do 2007 r. w podziale na sekcje według klasyfikacji PKD 2004, a druga w okresie od 2007 do 2011 r. według klasyfikacji PKD 2007. W artykule w związku z ograniczonym miejscem i chęcią kompleksowej prezentacji analizowanych mierników zamieszczono jedynie charakterystykę opisową wielkości bezwlędnych wybranych mierników oraz opisowotabelaryczno-graficzną ich zmian w postaci dynamiki.

Pierwszą poddaną analizie była liczba pracujących, która wyrażona jest w osobach. W okresie od 1998 r. do 2007 r. liczba pracujących zmniejszyła się z 3.037.034 do 2.573.600 i następnie wzrosła do 2.746.201 osób w 2011 r. W analizowanym okresie zaobserwować można wyraźne zmniejszenie liczby osób pracujących w latach 2002-2004. W 2003 r. odnotowano najmniejszą liczbę pracujących w całym analizowanym okresie (2.308.240). Najwięcej osób w całym analizowanym okresie pracowało w przedsiębiorstwach przetwórstwa przemysłowego. Łącznie $\mathrm{w}$ analizowanym okresie liczba osób pracujących zmniejszyła się o 684.453 pracujących. W okresie od 2007-2011 r. liczba osób pracujących nieznacznie się zmniejszyła (o 13.991 osób). W 9 sekcjach PKD odnotowano wzrost liczby pracujących. Największy wzrost w latach 2007-2011 odnotowano w dużych przedsiębiorstwach zajmujących się handlem hurtowym i detalicznym (+43.943). Natomiast największe zmniejszenie stanu zatrudnienia zaobserwowano w przetwórstwie przemysłowym o 111.442 pracujących. Zmiana klasyfikacji PKD nie zmieniła dominującej pozycji w liczbie osób pracujących $\mathrm{w}$ przedsiębiorstwach zajmujących się przetwórstwem przemysłowym (972.606).

Wyniki obliczeń dynamiki liczby pracujących w okresie od 1998 do 2011 roku przedstawiono $\mathrm{w}$ tab. 1 i 2. 


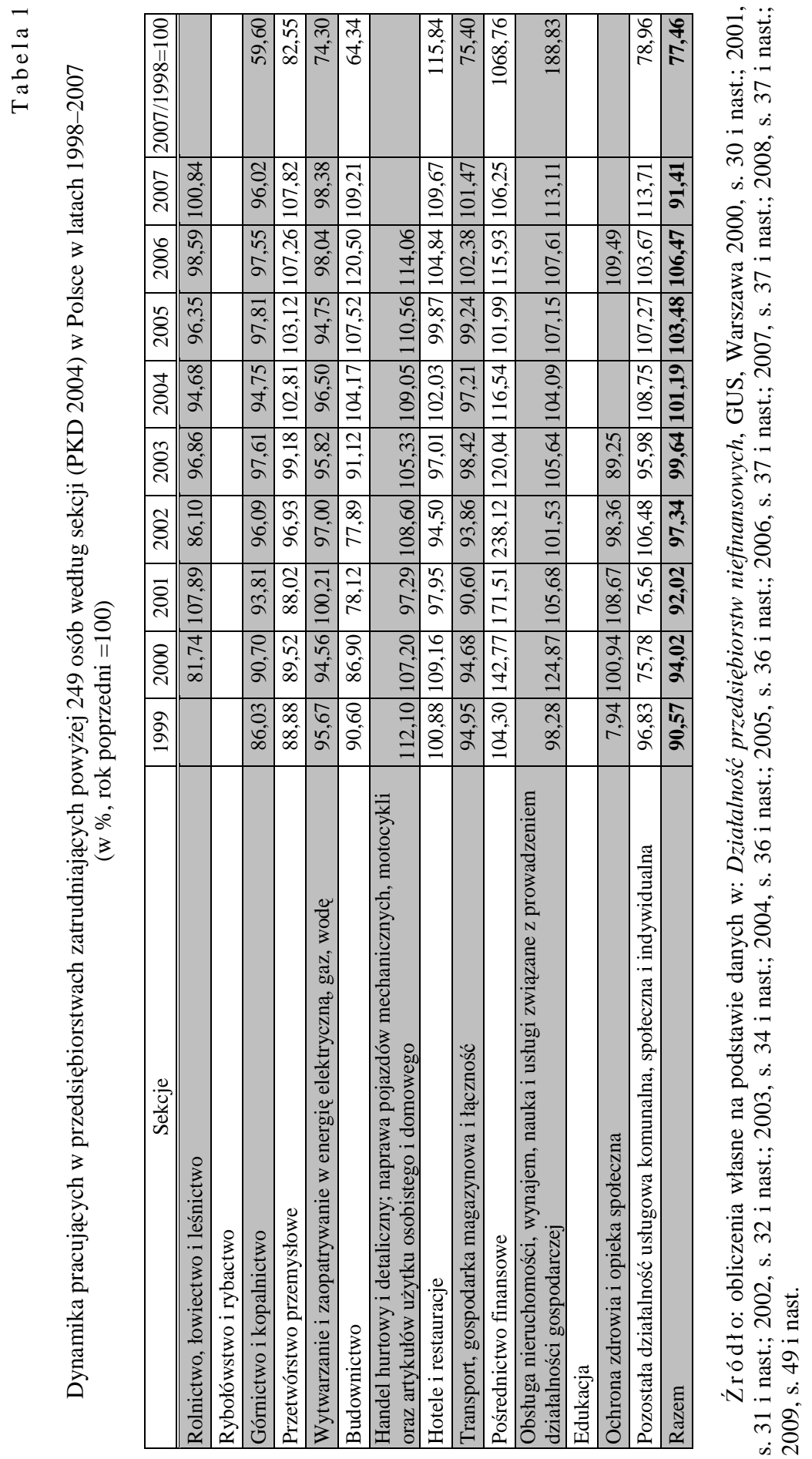




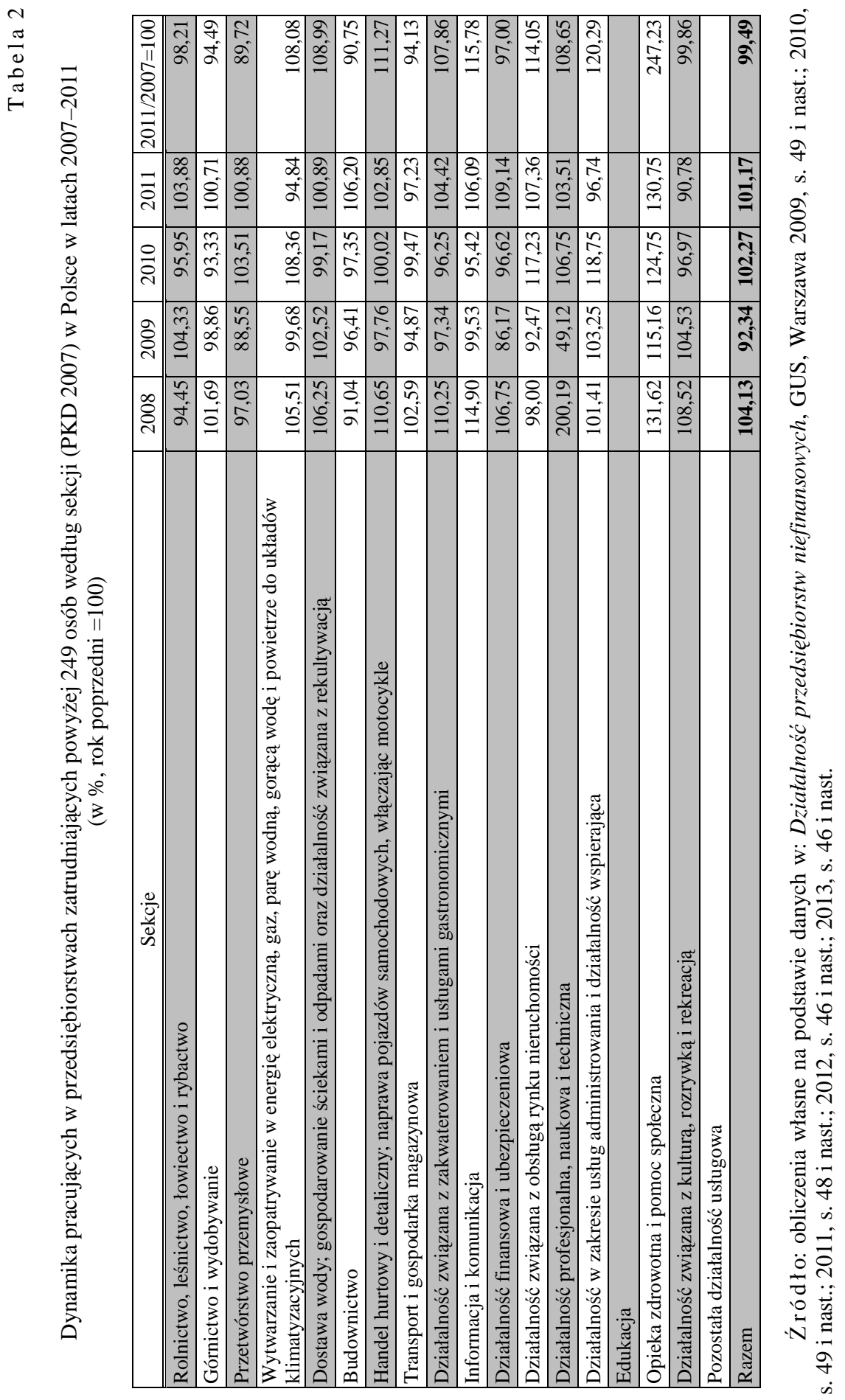


Cały okres analizy podzielono na dwa podokresy ze względu na zmianę klasyfikacji PKD (1998-2007 i 2007-2011). Wskaźnik dynamiki liczby osób pracujących w okresie 1998-2007 w dużych przedsiębiorstwach wyniósł 77,46\%. Jedynie w latach 2004-2006 liczba pracujących zwiększała się, na co wskazują wskaźniki dynamiki większe od 100. Analiza zmian w okresie od 1998 do 2007 r. wskazuje na bardzo duży wzrost liczby osób pracujących w przedsiębiorstwach zajmujących się pośrednictwem finansowym (1068\%).

Wzrosty liczby osób pracujących odnotowano jeszcze w przedsiębiorstwach zajmujących się handlem hurtowym i detalicznym, hotelami i restauracjami oraz obsługą nieruchomości. Największe zmniejszenie liczby pracujących odnotowano $\mathrm{w}$ górnictwie i kopalnictwie $(59,60 \%)$ oraz w budownictwie $(64,34 \%)$. W całym okresie od 1998 do 2007 r. coroczne zmniejszanie liczby pracujących zaobserwowano $\mathrm{w}$ przedsiębiorstwach zajmujących się wytwarzaniem i zaopatrywaniem w energię elektryczną, gaz i wodę oraz górnictwem i kopalnictwem. W dużych przedsiębiorstwach zajmujących się pośrednictwem finansowym, obsługa nieruchomości oraz handlem hurtowym i detalicznym w całym okresie od 1998 do 2007 r. odnotowano coroczne wzrosty liczby pracujących. W okresie 2007-2011 liczba pracujących nieznacznie zmniejszyła się $(99,49 \%)$ i z wyjątkiem 2009 roku liczba pracujących w dużych przedsiębiorstwach wzrastała corocznie (dynamika powyżej 100). W porównaniu do 2007 roku w 9 sekcjach odnotowano wzrost liczby pracujących, a w 7 ich zmniejszenie. Największy wzrost odnotowano w przedsiębiorstwach zajmujących się opieką zdrowotną i pomocą społeczną $(247,23 \%)$ oraz działalnością w zakresie usług administrowania i działalności wspierającej (120,29\%). W okresie od 2007 do 2011 r. jedynie w przedsiębiorstwach zajmujących się opieką zdrowotną i pomocą społeczną zaobserwowano coroczny wzrost liczby osób pracujących (dynamika o podstawie zmiennej powyżej 100). Największe przyrosty liczby pracujących we wszystkich sekcjach (dynamika o podstawie zmiennej) odnotowano w $2008 \mathrm{r}$. (zmniejszenie jedynie w 4 sekcjach) oraz w 2011 r. (zmniejszenie jedynie w 4 sekcjach).

Kolejnym miernikiem wielkości prowadzonej działalności gospodarczej i zarazem miernikiem struktury poddanym analizie była wartość środków trwałych dużych przedsiębiorstw. Wartość środków trwałych dużych przedsiębiorstw wzrosła z $285.642 \mathrm{mln}$ zł do $628.999 \mathrm{mln}$ zł w $2007 \mathrm{r}$. (+298.819 $\mathrm{mln}$ zł). Wartość środków trwałych w dużych przedsiębiorstwach wzrastała we wszystkich latach analizowanego okresu zarówno ogółem, jak i w przedsiębiorstwach wszystkich sekcji. Największą wartością środków trwałych w działalności gospodarczej dysponowały przedsiębiorstwa zajmujące się przetwórstwem przemysłowych oraz wytwarzaniem i zaopatrywaniem w energię elektryczną, gaz i wodę. Największy przyrost wartości środków trwałych odnotowano również w przedsiębiorstwach zakwalifikowanych do przetwórstwa przemysłowego oraz wytwarzania i zaopatrywania w energię elektryczną, gaz i wodę. Na pod- 
stawie danych zawartych w tabeli stwierdzić można, że w okresie od 2007 do 2011 r. wartość środków trwałych dużych podmiotów wzrosła o $282.608 \mathrm{mln}$ zł, osiągając w 2011 r. wartość 912.795 mln zł. We wszystkich sekcjach, z wyjątkiem budownictwa, odnotowano wzrost wartości środków trwałych w dużych podmiotach. W budownictwie zaobserwowano zmniejszenie ich wartości o $11.941 \mathrm{mln}$ zł w porównaniu do 2007 r. Analiza zmian wartości środków trwałych w dużych przedsiębiorstwach budowlanych wskazuje na znaczące zmniejszenie ich wartości już w 2010 r. Największy wzrost wartości środków trwałych, w okresie od 2007 do 2011 r., dużych przedsiębiorstwach odnotowano w podmiotach zajmujących się wytwarzaniem i zaopatrywaniem w energię elektryczną, gaz i wodę (+107.571 mln zł).

W tab. 3 i 4 przedstawiono dynamikę zmian wartości środków trwałych w dużych przedsiębiorstwach kolejno w latach 1998-2007 według klasyfikacji PKD 2004 (tab. 3) i w latach 2007-2011 według klasyfikacji PKD 2007 (tab. 4).

Wartość środków trwałych w dużych przedsiębiorstwach zwiększyła się w porównaniu do 1998 roku o 220,20\%. Analiza zmian dynamiki wskazuje na sukcesywne, coroczne, wzrosty wartości środków trwałych w dużych podmiotach. Największą dynamikę w porównaniu do 1998 roku zaobserwowano w dużych przedsiębiorstwach zajmujących się pośrednictwem finansowym $(738,71 \%)$ oraz handlem hurtowym i detalicznym (383,55\%). Najmniejszy wzrost wartości środków trwałych nastąpił w dużych przedsiębiorstwach zajmujących się górnictwem i kopalnictwem $(160,17 \%)$ oraz wytwarzaniem i zaopatrywaniem w energię elektryczną, gaz i wodę $(182,25 \%)$. Zmniejszenie wartości środków trwałych nastapiło: w rolnictwie i łowiectwie w latach 2000, 2001 i 2005, w przetwórstwie przemysłowym w 2001 r., w budownictwie w 2004 r., w hotelach i restauracjach w 2006 r., w transporcie i gospodarce magazynowej w 2004 r., w pośrednictwie finansowym w 2001, 2005 i 2006 r., w obsłudze nieruchomości w 2001, 2003 oraz 2005 r. W pozostałych latach odnotowano wzrost wartości środków trwałych.

W porównaniu do 2007 r. wartość środków trwałych zwiększyła się o 144,85. Największe przyrosty wartości środków trwałych zaobserwowano w podmiotach zajmujących się opieką zdrowotną i pomocą społeczną $(382,77 \%)$, działalnością profesjonalną, naukową i techniczną $(336,35 \%)$ oraz działalnością finansową i ubezpieczeniową (316,71\%). W porównaniu do $2007 \mathrm{r}$. jedynie $w$ dużych przedsiębiorstwach budowlanych wartość środków trwałych zmniejszyła się $(61,75 \%)$. Redukcję wartości środków trwałych w dużych przedsiębiorstwach budowlanych odnotowano już w 2009 r. (96,84\%). W przedsiębiorstwach pozostałych sekcji działalności gospodarczej w porównaniu do $2007 \mathrm{r}$. odnotowano wzrost wartości środków trwałych. Zmniejszenia wartości środków trwałych odnotowano również w przedsiębiorstwach handlowych w 2010 i $2011 \mathrm{r}$. oraz $\mathrm{w}$ przedsiębiorstwach zajmujących się rolnictwem i łowiectwem w 2008 i 2009 r. 


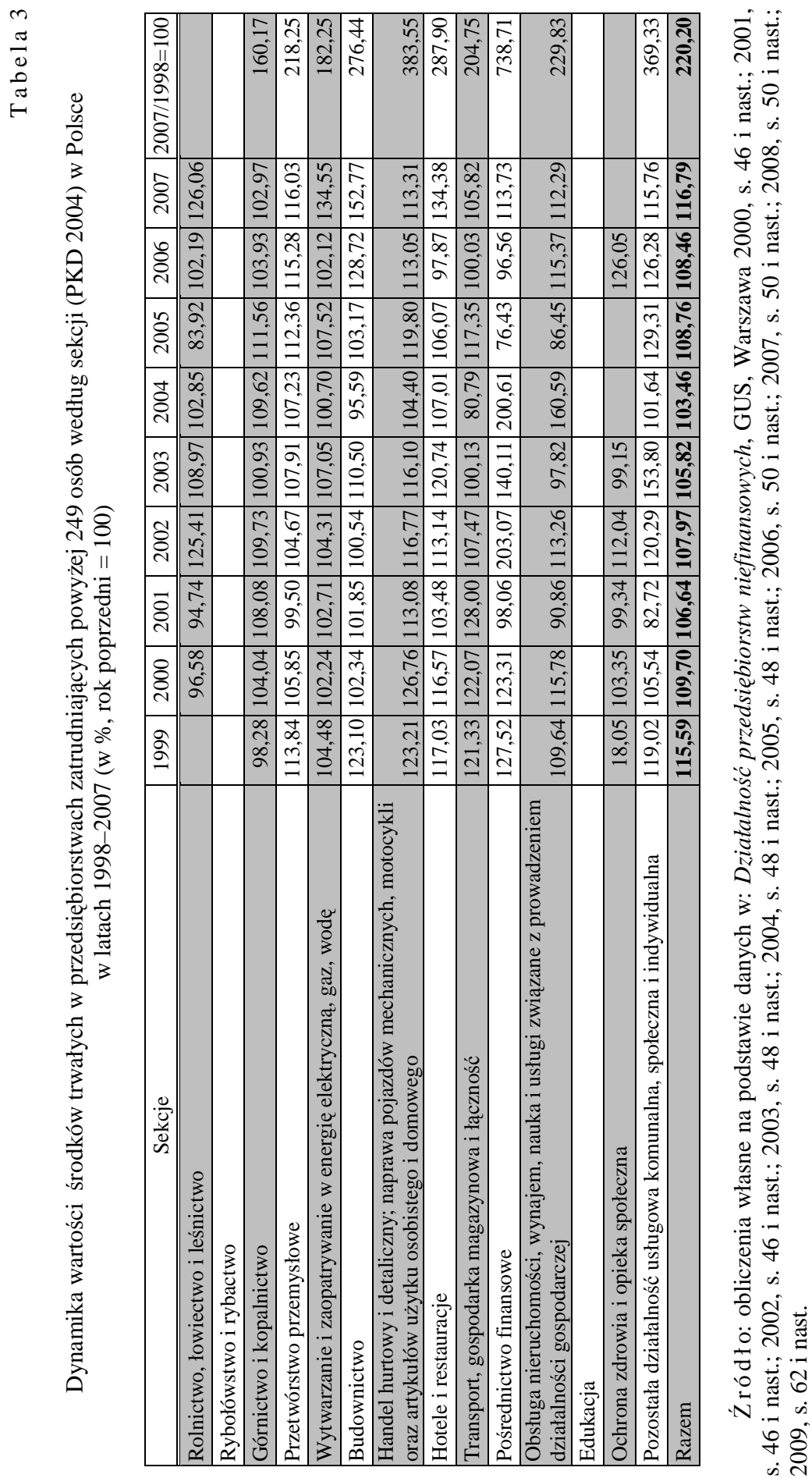




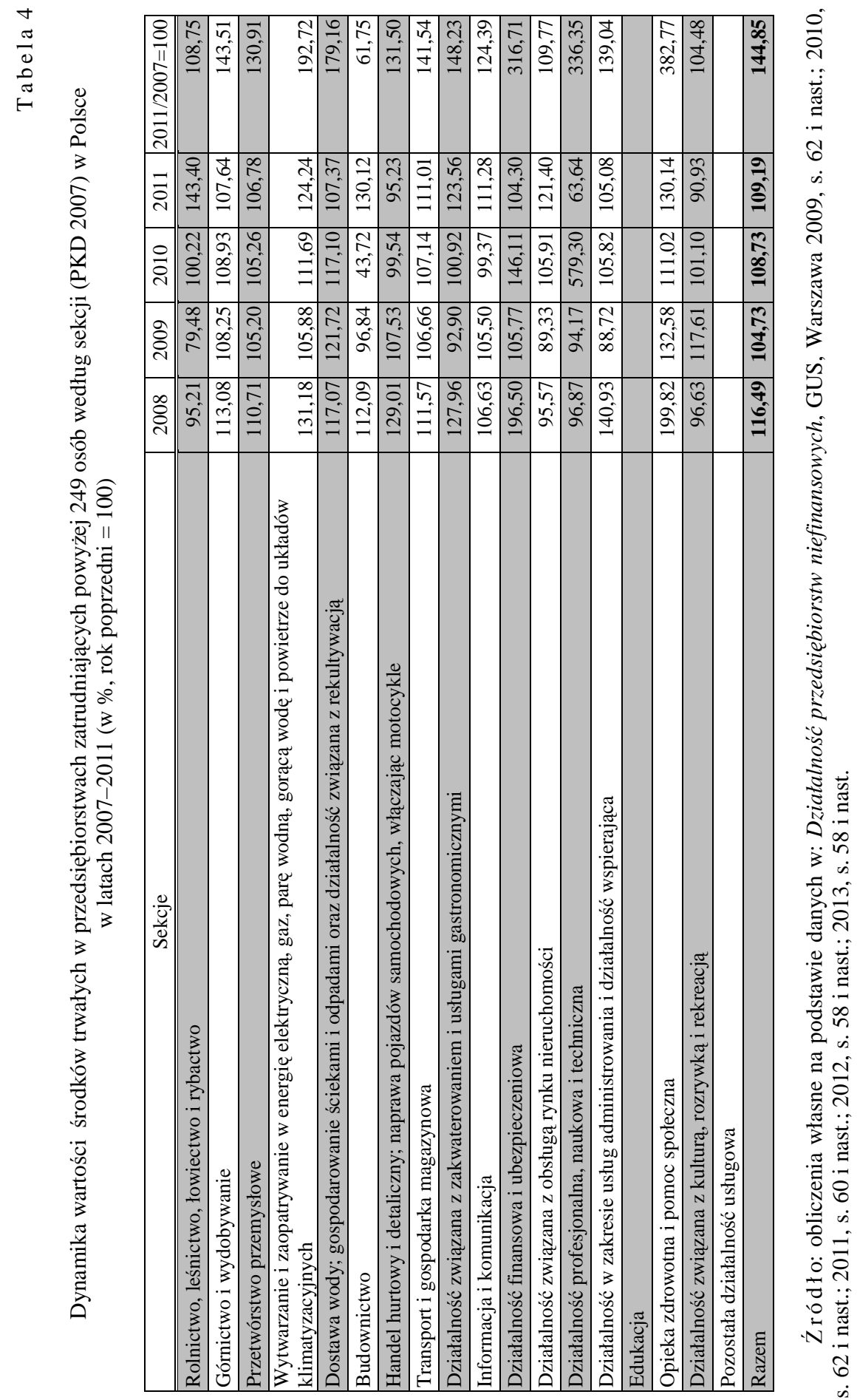


Kolejnym miernikiem poddanym analizie była wartość nakładów inwestycyjnych ponoszonych przez duże przedsiębiorstwa w latach 1998-2007 według klasyfikacji PKD 2004 i w latach 2007-2011 według klasyfikacji PKD 2007. Wartość nakładów inwestycyjnych w dużych przedsiębiorstwach w porównaniu do 1998 r. wzrosła w 2007 r. o 26.337 mln zł. Najmniejszą wartość ponoszonych nakładów inwestycyjnych odnotowano w 2003 roku (41.912 mln zł) oraz w 2002 r. (42.412 mln zł). W okresie od 2001 r. do 2004 r. odnotowano znaczące zmniejszenie wartości ponoszonych nakładów inwestycyjnych przez duże przedsiębiorstwa. Nakłady inwestycyjne dużych przedsiębiorstw kształtowały się na najwyższym poziomie w całym analizowanym okresie i były 1,73 razy większe od nakładów inwestycyjnych w 2003 r. W porównaniu do 1998 r. we wszystkich sekcjach PKD odnotowano wzrost wartości ponoszonych nakładów inwestycyjnych. Największy wzrost nakładów inwestycyjnych odnotowano w dużych przedsiębiorstwach zajmujących się przetwórstwem przemysłowym (+11.699 mln zł). Również te przedsiębiorstwa ponosiły największe nakłady na inwestycje. W dużych przedsiębiorstwach przetwórstwa przemysłowego odnotowano w okresie 2000 i 2001 zmniejszenie wydatkowanych nakładów inwestycyjnych. W kolejnych latach następował wzrost wartości inwestycji w tej grupie przedsiębiorstw. Znaczące zmniejszenie wartości nakładów inwestycyjnych zaobserwowano również w dużych przedsiębiorstwach zajmujących się transportem i gospodarką magazynową w latach 2001-2003. W latach 2001-2003 w 5 sekcjach odnotowano zmniejszenie wartości nakładów inwestycyjnych. W okresie od 2007 r. do 2011 r. wartość nakładów inwestycyjnych wzrosła o 556 mln zł. Największą wartość nakładów inwestycyjnych duże przedsiębiorstwa poniosły w 2008 r. (86.515 mln zł). W latach 2009 i 2010 nastąpiło zmniejszenie wartości inwestycji w dużych podmiotach. W kolejnym roku wartość nakładów inwestycyjnych została zwiększona. W porównaniu do 2007 r. jedynie w 7 sekcjach PKD odnotowano wzrost wartości ponoszonych nakładów inwestycyjnych. Największy wzrost dotyczył przedsiębiorstw zakwalifikowanych do sekcji wytwarzanie i zaopatrywania w energię elektryczna, gaz i wodę $(+6.850$ mln zł) oraz transportu i gospodarki magazynowej (+3.759 mln zł). Największe zmniejszenie wartości nakładów inwestycyjnych zaobserwowano w dużych przedsiębiorstwach zajmujących się przetwórstwem przemysłowym $(-6.788 \mathrm{mln}$ zł) i działalnością finansową i ubezpieczeniową (-2.777 mln zł). W latach 2009 i 2010 można zaobserwować zmniejszenie wartości inwestycji w większości sekcji PKD. W analizowanym okresie jedynie w przedsiębiorstwach zajmujących się wytwarzaniem i zaopatrywaniem w energię elektryczną, gaz i wodę oraz opieką zdrowotną i pomocą społeczną zaobserwowano regularny (coroczny) wzrost wartości ponoszonych nakładów inwestycyjnych. 
$n$
$n$
0
0
0
0
0

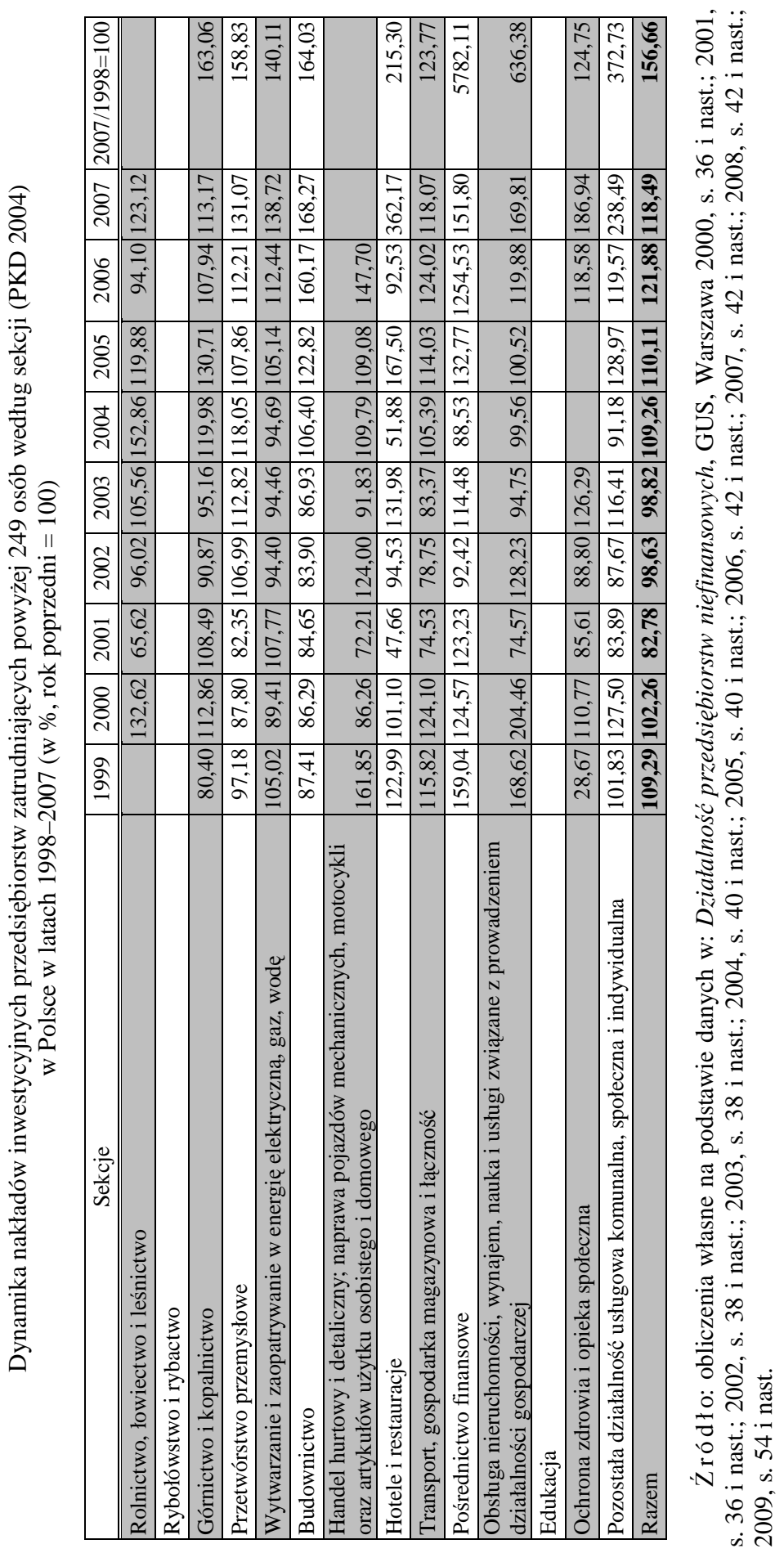




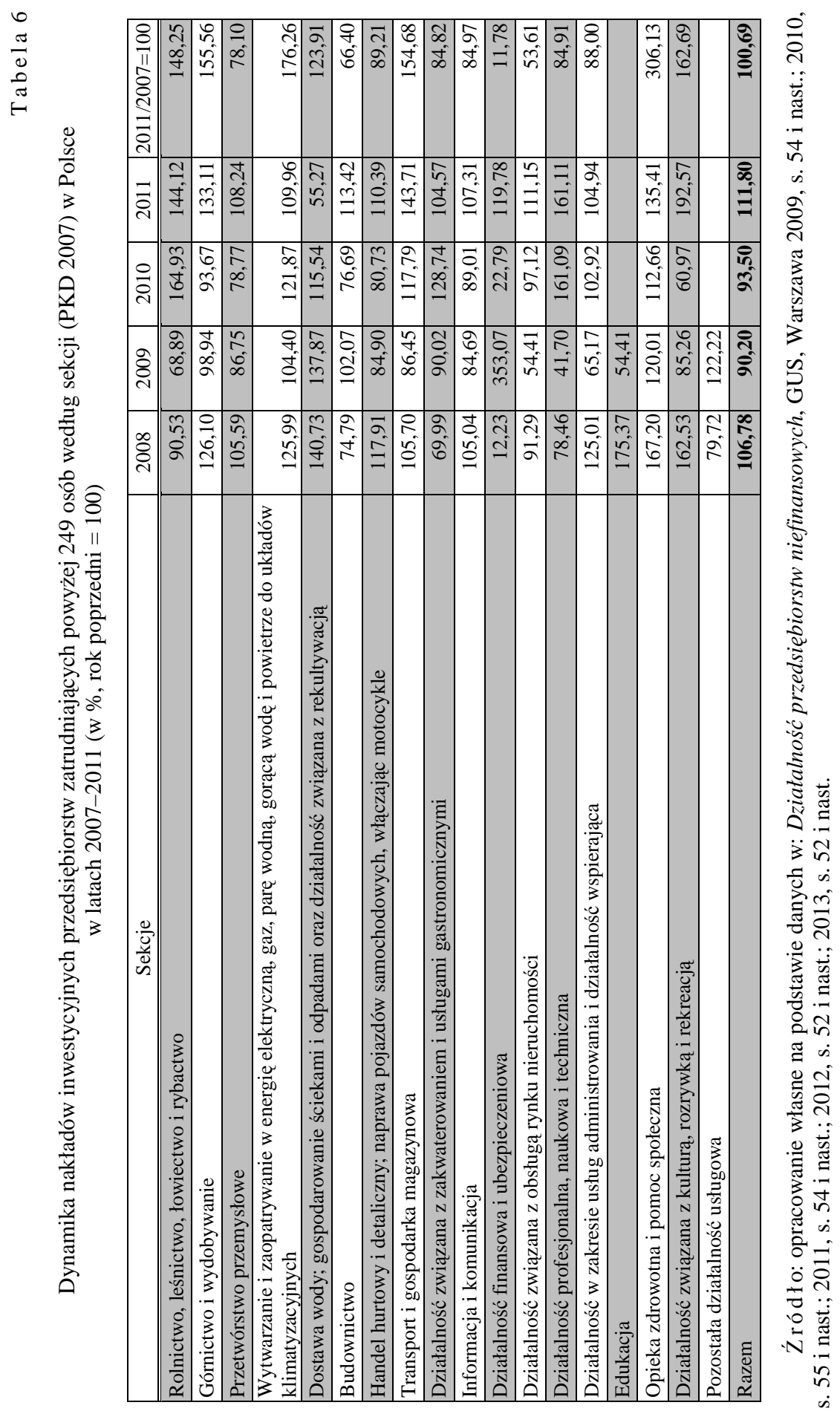


W tab. 5 i 6 przedstawiono dynamikę zmian wartości nakładów inwestycyjnych w dużych przedsiębiorstwach w latach 1998-2007 według klasyfikacji PKD 2004 (tab. 5) i 2007-2011 według klasyfikacji PKD 2007 (tab. 6). W porównaniu do 1998 r. wartość nakładów inwestycyjnych zwiększyła się o 56,66\%. W latach 2001-2003 nastąiło zmniejszenie wartości ponoszonych nakładów inwestycyjnych przez duże podmioty. W kolejnych latach obserwowano wzrost ich wartości. W porównaniu do $1998 \mathrm{r}$. we wszystkich sekcjach PKD nastąpił wzrost wartości nakładów inwestycyjnych. Największą dynamikę wzrostu w porównaniu do 1998 r. zaobserwowano w przedsiębiorstwach zajmujących się pośrednictwem finansowym (5782\%) oraz obsługą nieruchomości, wynajmem, nauką i usługami związanym z prowadzeniem działalności gospodarczej (636\%). W latach 2001 i 2002 jedynie w 3 sekcjach odnotowano wzrost wartości inwestycji, lecz był on na niskim poziomie. W kolejnych latach 2003 i 2004 już w 6 sekcjach obserwowano wzrost nakładów inwestycyjnych. W latach 2005 i 2007 we wszystkich sekcjach nastapił wzrost nakładów inwestycyjnych. Na podstawie danych w kolejnej tabeli (tab. 6) zaobserwować można praktycznie brak wzrostu nakładów inwestycyjnych dużych podmiotów (100,69\%). W latach 2009 i 2010 nastąpiło zmniejszenie inwestycji w dużych przedsiębiorstwach. W porównaniu do 2007 r. jedynie w 7 sekcjach nastąpiło zwiększenie wartości inwestycji. W pozostałych sekcjach odnotowano zmniejszenie ich wartości. W 2009 r. jedynie w 6 sekcjach nastapił wzrost inwestycji, a w 2010 w 8 sekcjach. W 2011 r. wzrostu wartości nakładów inwestycyjnych nie odnotowano jedynie w przedsiębiorstwach zajmujących się dostawą wody, gospodarowaniem ściekami i odpadami oraz działalnością rekultywacyjną $(55,27 \%)$.

W 2007 r. wartość przychodów ze sprzedaży dużych przedsiębiorstw wynosiła $779.833 \mathrm{mln}$ zł i była większa o $447.629 \mathrm{mln}$ zł od wartości przychodów w 1998 r. W całym analizowanym okresie następował coroczny wzrost wartości przychodów ze sprzedaży. W porównaniu do $1998 \mathrm{r}$. we wszystkich sekcjach PKD nastąpił wzrost przychodów ze sprzedaży w dużych przedsiębiorstwach. Największy wzrost dotyczył przedsiębiorstw przetwórstwa przemysłowego (+274.163 mln zł). W całym analizowanym okresie we wszystkich sekcjach zaobserwowano regularny wzrost wartości osiaganych przychodów ze sprzedaży. Największą wartość przychodów w całym okresie od 1998 r. do 2007 r. osiagnęły przedsiębiorstwa zajmujące się przetwórstwem przemysłowym.

W porównaniu do $2007 \mathrm{r}$. (tab. 7) nastąpił wzrost wartości przychodów ze sprzedaży o $242.671 \mathrm{mln}$ zł. W 2009 r. nastapiło nieznaczne zmniejszenie wartości przychodów dużych przedsiębiorstw ( $-4.355 \mathrm{mln}$ zł w porównaniu do 2008 r.). $\mathrm{W}$ tym roku w 7 sekcjach nastąpiło zmniejszenie wartości osiąganych przychodów ze sprzedaży. 


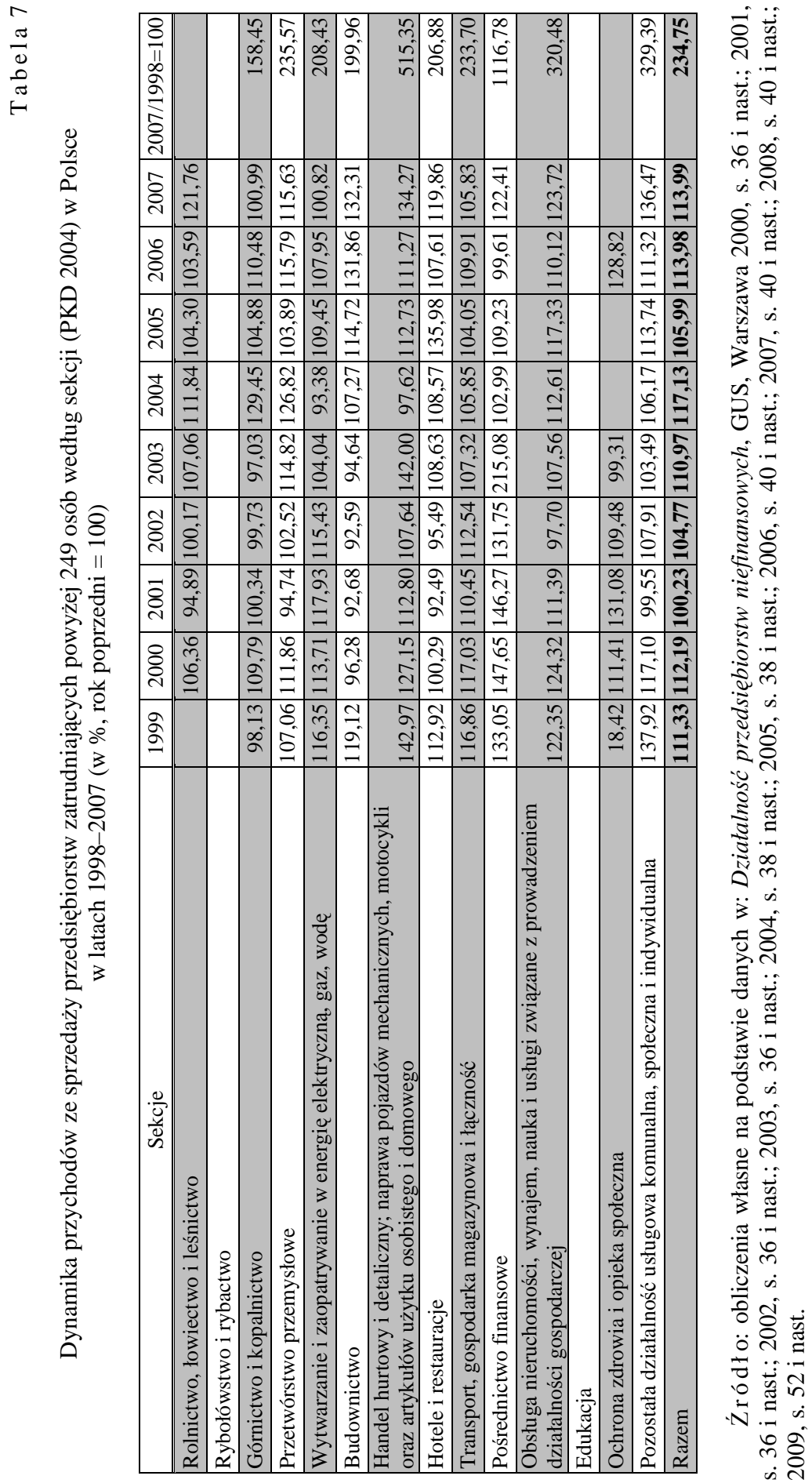


$\infty$
0
0
0
0
0

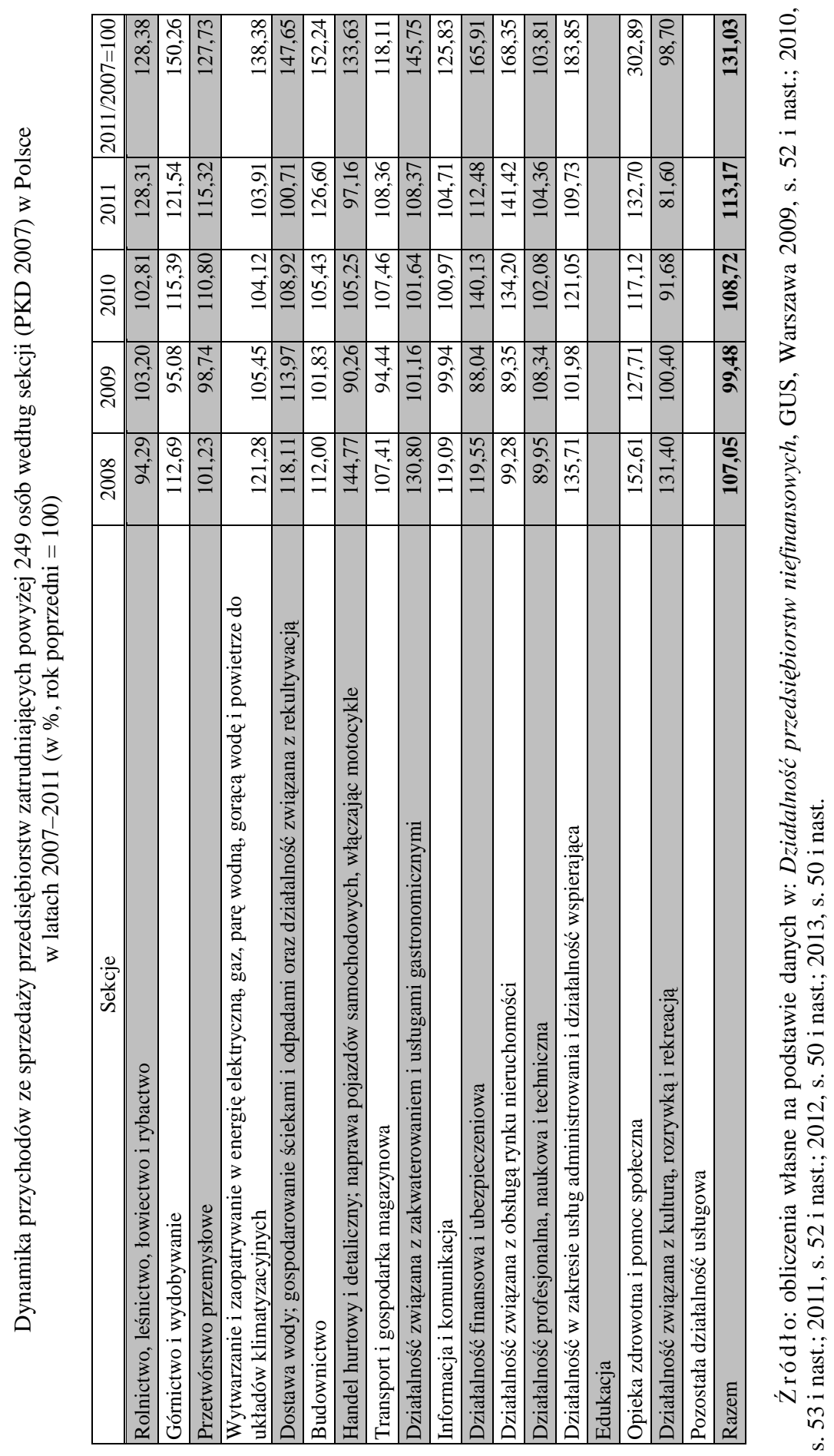


W porównaniu do 2007 r. we wszystkich sekcjach PKD odnotowano wzrost wartości osiaganych przychodów ze sprzedaży. Największy przyrost przychodów ze sprzedaży dotyczył dużych przedsiębiorstw zajmujących się przetwórstwem przemysłowym $(+130.582 \mathrm{mln}$ zł).

Wyniki obliczeń dynamiki wartości przychodów ze sprzedaży w dużych przedsiębiorstwach w latach 1998-2007 według klasyfikacji PKD 2004 zamieszczono w tab. 7, natomiast w latach 2007-2011 według klasyfikacji PKD 2007 (tab. 8).

W 2007 r. w porównaniu do 1998 r. wskaźnik dynamiki wartości przychodów ze sprzedaży ogółem w przedsiębiorstwach dużych wyniósł 234,75\%. Wartość dynamiki przychodów ze sprzedaży w okresie od 1998 r. do 2007 r. kształtowała się na poziomie większym od 100, co oznacza regularny wzrost wartości przychodów w tej grupie przedsiębiorstw. W porównaniu do $1998 \mathrm{r}$. we wszystkich sekcjach PKD odnotowano wzrost wartości przychodów. Największa wartość dynamiki dotyczyła dużych przedsiębiorstw zajmujących się pośrednictwem finansowym $(1116,78 \%)$ oraz handlem hurtowym i detalicznym (515,35\%). W latach 2000-2003 przedsiębiorstwa budowlane zmniejszały wartość osiąganych przychodów ze sprzedaży oraz górnictwo i kopalnictwo w 2002 i $2003 \mathrm{r}$.

W porównaniu do 2007 roku (tab. 7) dynamika wartości przychodów dużych przedsiębiorstw wyniosła 131,03\%. W 2009 r., podobnie jak w przypadku nakładów inwestycyjnych, przychody dużych przedsiębiorstw zmniejszyły się do poziomu 99,48\% przychodów 2008 r., co miało wpływ na zmniejszenie wartości osiaganych przychodów ze sprzedaży w 7 sekcjach PKD (górnictwo i wydobywanie, przetwórstwo przemysłowe, handel hurtowy i detaliczny, transport i gospodarka magazynowa, informacja i komunikacja, działalność finansowa i ubezpieczeniowa, działalność związana $\mathrm{z}$ obsługą rynku nieruchomości). W 2011 r. zmniejszenie przychodów ze sprzedaży dotyczyło jedynie przedsiębiorstw zajmujących się handlem hurtowym i detalicznym.

\section{TENDENCJE I KIERUNKI ZMIAN DZIAŁALNOŚCI GOSPODARCZEJ DUŻYCH PRZEDSIĘBIORSTW W POLSCE}

W celu prezentacji zmian i ukazania tendencji dotyczącej dynamiki wybranych mierników obliczone wartości wskaźników dynamiki zaprezentowanych w tabelach 1-8 przedstawiono w formie wykresu (rys. 1) oraz w postaci map (mapy 1-8). Na rys. 1 przedstawiono porównanie dynamiki ogółem czterech analizowanych mierników. Na podstawie graficznej ilustracji zaobserwować można dwa okresy zmniejszenia dynamiki wzrostu czterech wybranych mierników: jest to 2001 i 2009 r. W 2001 r. zaobserwować można zmniejszenie liczby pracujących oraz nakładów inwestycyjnych, a w 2009 r. zmniejszenie wartości 
objęło już trzy mierniki (przychody ze sprzedaży, nakłady inwestycyjne oraz liczbę pracujących). W całym okresie analizy jedynie wartość środków trwałych cechowała się regularnym wzrostem (wartość dynamiki powyżej 100\%), a wartość dynamiki przychodów ze sprzedaży jedynie w 2009 r. osiągnęła poziom niższy od $100 \%(99,48 \%)$. W pozostałych latach przychody ze sprzedaży cechowały się wzrostem. Ilustracja graficzna dynamiki zmian analizowanych mierników pozwala na stwierdzenie, że najgłębsze zmiany wartości w całym analizowanym okresie dotyczyły nakładów inwestycyjnych (największa amplituda zmian) oraz liczby osób pracujących. Na podstawie ilustracji graficznej zaobserwować można trend wzrostowy liczby osób pracujących oraz nakładów inwestycyjnych.

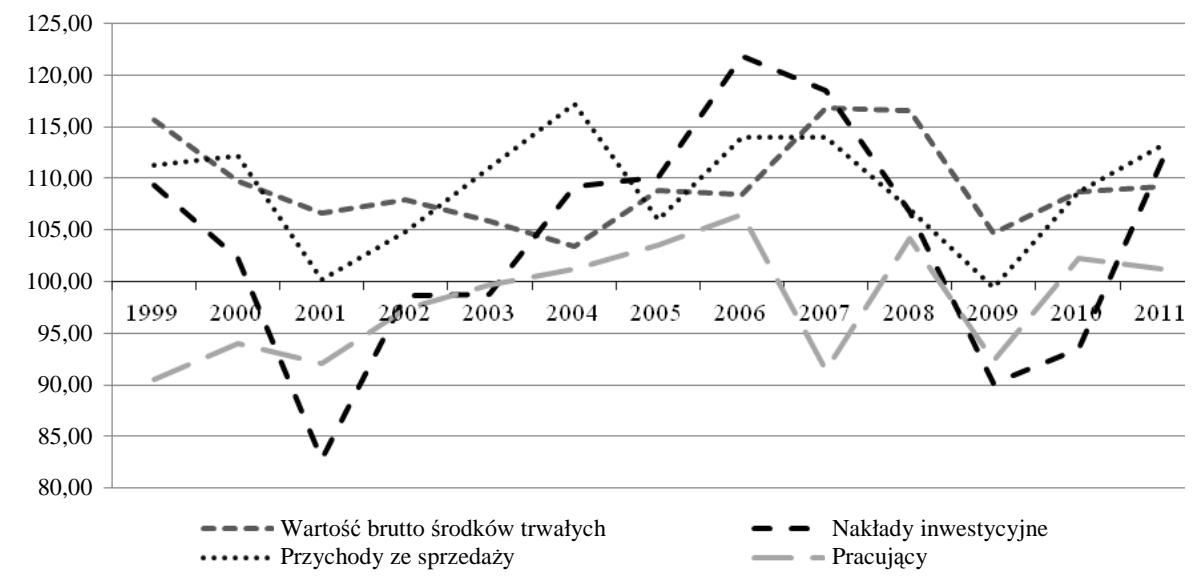

Rys. 1. Dynamika zmian wartości ogółem wybranych mierników dużych przedsiębiorstw $\mathrm{w}$ Polsce w latach 1998-2011 (w \%, rok poprzedni $=100)$

Źródło: opracowanie własne na podstawie danych w tab. 1-8.

Dane dotyczące dynamiki zmian analizowanych mierników zawarte w tabelach 1-8 zaprezentowano w postaci graficznych map, gdzie kolor lㅔ씰 przyporządkowany został wartości współczynnika dynamiki wynoszącej powyżej $100 \%$ (oznaczając przyrost wartości miernika w stosunku do roku poprzedniego). Komórki w których występuje kolor szary wskazują na wartość dynamiki danego miernika poniżej 100\% (zmniejszenie wartości miernika). Na podstawie graficznej ilustracji przedstawionej na mapach 1 i 2 obrazujących zmiany dynamiki liczby osób pracujących w dużych przedsiębiorstwach w Polsce stwierdzić można, że w okresie od 1998 do 2007 r. regularny wzrost liczby pracujących odnotowano w przedsiębiorstwach zajmujących się pośrednictwem finansowym oraz obsługą nieruchomości, wynajmem, nauką i usługami związanymi z prowadzeniem działalności gospodarczej. 


\begin{tabular}{|c|c|c|c|c|c|c|c|c|c|}
\hline SEKCJE & 1999 & 2000 & 2001 & 2002 & 2003 & 2004 & 2005 & 2006 & 2007 \\
\hline \multicolumn{10}{|l|}{$\begin{array}{l}\text { ROLNICTWO, ŁOWIECTWO I } \\
\text { LEŚNICTWO } \\
\end{array}$} \\
\hline \multicolumn{10}{|l|}{ RYBOtÓWSTWO I RYBACTWO } \\
\hline GÓRNICTWO I KOPALNICTWO & - & $+\cdots$ & - & - & $\cdots$ & & - & 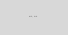 & 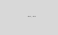 \\
\hline \multicolumn{10}{|l|}{ PRZETWÓRSTWO PRZEMYStOWE } \\
\hline \multicolumn{10}{|l|}{\begin{tabular}{|} 
WYTWARZANIE IZAOPATRYWANIE \\
W ENERGIE ELEKTRYCZNA, GAZ,
\end{tabular}} \\
\hline \multicolumn{10}{|l|}{ BUDOWNICTWO } \\
\hline \multicolumn{10}{|l|}{\begin{tabular}{|c|} 
HANDEL HURTOWY IDETALICZNY; \\
NAPRAWA POJAZDÓW \\
\end{tabular}} \\
\hline \multicolumn{10}{|l|}{ HOTELE I RESTAURACJE } \\
\hline \multicolumn{10}{|l|}{$\begin{array}{l}\text { TRANSPORT, GOSPODARKA } \\
\text { MAGAZYNOWAILACZNOŚĆ }\end{array}$} \\
\hline \multicolumn{10}{|l|}{ POŚREDNICTWO FINANSOWE } \\
\hline \multicolumn{10}{|l|}{$\begin{array}{l}\text { OBStUGA NIERUCHOMOŚCI, } \\
\text { WYNAJEM, NAUKA I UStUG } \\
\end{array}$} \\
\hline \multicolumn{10}{|l|}{ EDUKACJA } \\
\hline \multicolumn{10}{|l|}{$\begin{array}{l}\text { OCHRONA ZDROWIA I OPIEKA } \\
\text { SPOLECZNA }\end{array}$} \\
\hline \multicolumn{10}{|l|}{$\begin{array}{l}\text { POZOSTALA DZIALALNOŚĆ } \\
\text { UStUGOWA KOMUNALNA, }\end{array}$} \\
\hline & ość dyn & ki poni & $00 \%$ & & & & & & \\
\hline we & ość dyn & i powy & $00 \%$ & & & & & & \\
\hline
\end{tabular}

Mapa 1. Mapa dynamiki pracujących w przedsiębiorstwach zatrudniających powyżej 249 osób według sekcji (PKD 2004) w Polsce w latach 1998-2007

Źródło: opracowanie własne na podstawie danych zawartych w tab. 1.

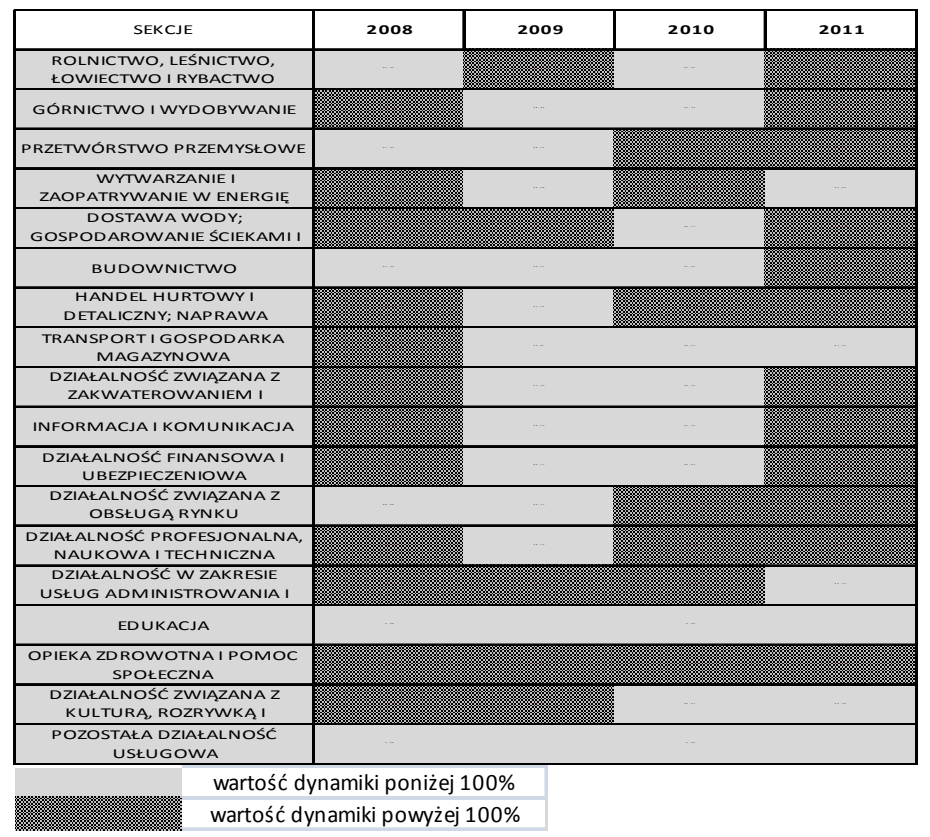

Mapa 2. Mapa dynamiki pracujących w przedsiębiorstwach zatrudniających powyżej 249 osób według sekcji (PKD 2007) w Polsce w latach 2007-2011 Źródło: opracowanie własne na podstawie danych zawartych w tab. 2. 
W okresie od 2004 do 2007 r. wzrost liczby osób pracujących odnotowano również w dużych przedsiębiorstwach zajmujących się przetwórstwem przemysłowym, budownictwem oraz pozostałą działalnością usługową komunalną, społeczną i indywidualną. W przedsiębiorstwach zakwalifikowanych do sekcji handel hurtowy i detaliczny; naprawa pojazdów mechanicznych i motocykli jedynie w 2001 r. zaobserwowano zmniejszenie liczby osób w nich pracujących. Okres 2004 do 2008 r. (mapa 1 i 2) cechuje się zwiększaniem liczby pracujących w dużych przedsiębiorstwach. Na podstawie danych zawartych na mapie 2 zauważyć można, że w 2009 r. odnotowano zmniejszenie liczby osób pracujących praktycznie we wszystkich sekcjach PKD (wzrost jedynie w 5 sekcjach). W 2011 r. odnotowano wzrost liczby pracujących w 12 sekcjach.

Wartość dynamiki środków trwałych dużych przedsiębiorstw kształtowała się na wyższym poziomie niż liczby osób pracujących. W okresie od 1998 do 2007 r. coroczny wzrost wartości środków trwałych w dużych przedsiębiorstwach odnotowano w podmiotach zajmujących wytwarzaniem i zaopatrywaniem w energię elektryczną, gaz i wodę oraz handlem hurtowym i detalicznym, naprawą pojazdów mechanicznych, motocykli oraz artykułów użytku osobistego. W latach 2007 do 2011 dynamika wartości środków trwałych kształtowała się na poziomie większym od $100 \mathrm{w}$ przedsiębiorstwach zajmujących się górnictwem i wydobywaniem, przetwórstwem przemysłowym, wytwarzaniem i zaopatrywaniem w energię elektryczną, gaz, parę wodną, gorącą wodę i powietrze do układów klimatyzacyjnych, dostawą wody i gospodarowaniem ściekami i odpadami, transportem i gospodarką magazynową, działalnością finansową i ubezpieczeniową oraz opieką zdrowotną i pomocą społeczną. W latach 2010 i 2011 odnotowano zmniejszenie wartości środków trwałych w dużych przedsiębiorstwach zakwalifikowanych do handlu hurtowego i detalicznego, naprawy pojazdów mechanicznych, motocykli oraz artykułów użytku osobistego.

Analiza zmian dynamiki nakładów inwestycyjnych dużych przedsiębiorstw wskazuje na brak sekcji PKD 2004, które cechowały się regularnym wzrostem wartości inwestycji. Na podstawie ilustracji graficznej przedstawionej na mapie 5 stwierdzić można, że okres 2001-2004 cechował się zmniejszaniem wartości nakładów inwestycyjnych w większości sekcji PKD. Na uwagę zasługuje wzrost wartości nakładów inwestycyjnych od 2002 r. przedsiębiorstw przetwórstwa przemysłowego oraz od 2004 roku przedsiębiorstw górnictwa i kopalnictwa i budownictwa. W okresie od 2007 do 2011 r. regularny (coroczny) wzrost wartości nakładów inwestycyjnych dużych przedsiębiorstw zaobserwowano w przedsiębiorstwach zajmujących się wytwarzaniem i zaopatrywaniem w energię elektryczną, gaz, parę wodną, gorącą wodę i powietrze do układów klimatyzacyjnych oraz opieką zdrowotną i pomocą społeczną. W $2011 \mathrm{r}$. wzrost nakładów inwestycyjnych odnotowano we wszystkich sekcjach PKD z wyjątkiem przedsiębiorstw zajmujących się dostawą wody, gospodarowaniem ściekami i odpadami oraz działalnością związaną z rekultywacją. 


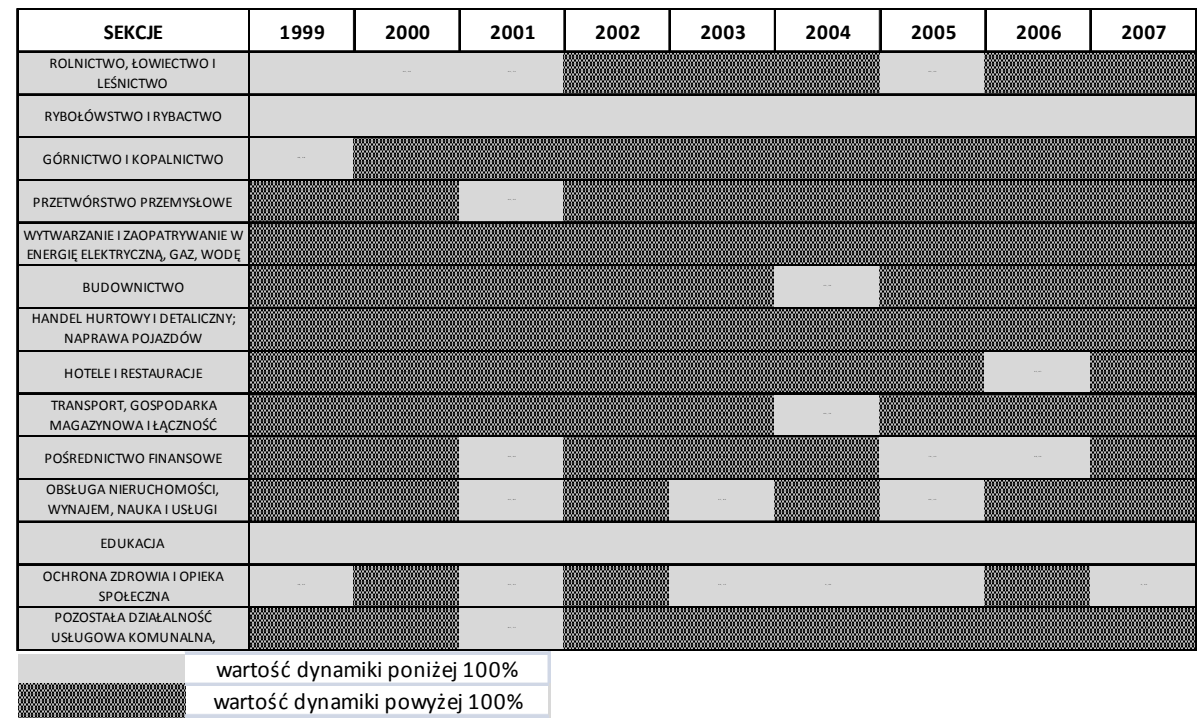

Mapa 3. Mapa dynamiki wartości środków trwałych przedsiębiorstw zatrudniających powyżej 249 osób według sekcji (PKD 2004) w Polsce w latach 1998-2007

Źródło: opracowanie własne na podstawie danych zawartych w tab. 3.

\begin{tabular}{|c|c|c|c|c|}
\hline SEKCJE & 2008 & 2009 & 2010 & 2011 \\
\hline \multicolumn{5}{|l|}{$\begin{array}{l}\text { ROLNICTWO, LEŚNICTWO, } \\
\text { ŁOWIECTWO I RYBACTWO }\end{array}$} \\
\hline \multicolumn{5}{|l|}{ GÓRNICTWO I WYDOBYWANIE } \\
\hline \multicolumn{5}{|l|}{ PRZETWÓRSTWO PRZEMYStOWE } \\
\hline \multicolumn{5}{|l|}{$\begin{array}{l}\text { WYTWARZANIE I ZAOPATRYWANIE } \\
\text { W ENERGIĘ ELEKTRYCZNA, GAZ, }\end{array}$} \\
\hline \multicolumn{5}{|l|}{$\begin{array}{c}\text { DOSTAWA WODY; } \\
\text { GOSPODAROWANIE ŚCIEKAMII }\end{array}$} \\
\hline \multicolumn{5}{|l|}{ BUDOWNICTWO } \\
\hline \multicolumn{5}{|l|}{$\begin{array}{l}\text { HANDEL HURTOWY I DETALICZNY; } \\
\text { NAPRAWA POJAZDÓW }\end{array}$} \\
\hline \multicolumn{4}{|l|}{$\begin{array}{l}\text { TRANSPORT I GOSPODARKA } \\
\text { MAGAZYNOWA }\end{array}$} & \\
\hline \multicolumn{5}{|l|}{$\begin{array}{l}\text { DZIALALNOŚĆ ZWIAZANA Z } \\
\text { ZAKWATEROWANIEM I }\end{array}$} \\
\hline \multicolumn{5}{|l|}{ INFORMACJA I KOMUNIKACJA } \\
\hline \multicolumn{5}{|l|}{$\begin{array}{l}\text { DZIALALNOŚĆ FINANSOWA I } \\
\text { UBEZPIECZENIOWA }\end{array}$} \\
\hline \multicolumn{5}{|l|}{$\begin{array}{c}\text { DZIAtALNOŚĆ ZWIAZANA Z } \\
\text { OBStUGA RYNKU }\end{array}$} \\
\hline \multicolumn{5}{|l|}{$\begin{array}{l}\text { DZIAŁALNOŚĆ PROFESJONALNA, } \\
\text { NAUKOWA I TECHNICZNA }\end{array}$} \\
\hline \multicolumn{5}{|l|}{$\begin{array}{l}\text { DZIAtALNOŚĆ W ZAKRESIE UStUG } \\
\text { ADMINISTROWANIA I }\end{array}$} \\
\hline \multicolumn{5}{|l|}{ EDUKACJA } \\
\hline \multicolumn{5}{|l|}{$\begin{array}{l}\text { OPIEKA ZDROWOTNA I POMOC } \\
\text { SPOLECZNA }\end{array}$} \\
\hline \multicolumn{5}{|l|}{$\begin{array}{l}\text { DZIAtALNOŚĆ ZWIAZANA Z } \\
\text { KULTURA, ROZRYWKA, I }\end{array}$} \\
\hline \multicolumn{5}{|l|}{$\begin{array}{l}\text { POZOSTAtA DZIAtALNOŚĆ } \\
\text { UStUGOWA }\end{array}$} \\
\hline wartość d & niki po & & & \\
\hline wartość d & liki pou & $\%$ & & \\
\hline
\end{tabular}

Mapa 4. Mapa dynamiki wartości środków trwałych przedsiębiorstw zatrudniających powyżej 249 osób według sekcji (PKD 2007) w Polsce w latach 2007-2011

Źródło: opracowanie własne na podstawie danych zawartych w tab. 4. 


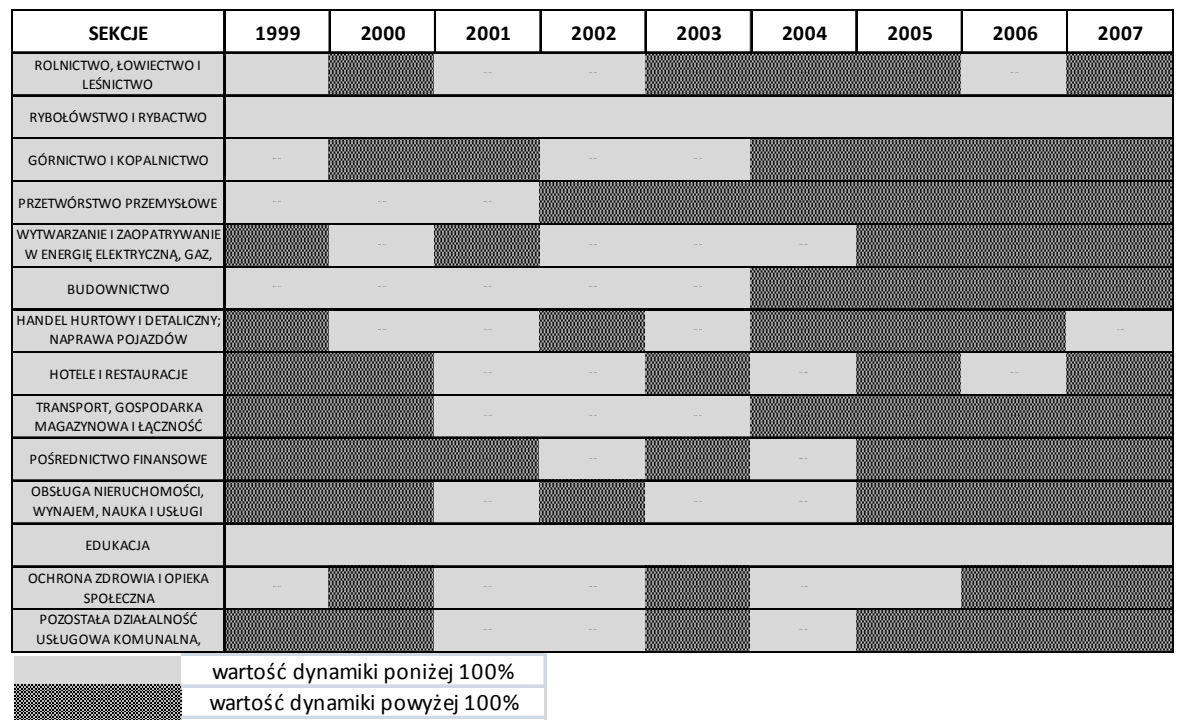

Mapa 5. Mapa dynamiki nakładów inwestycyjnych przedsiębiorstw zatrudniających powyżej 249 osób według sekcji (PKD 2004) w Polsce w latach 1998-2007

Źródło: opracowanie własne na podstawie danych zawartych w tab. 5.

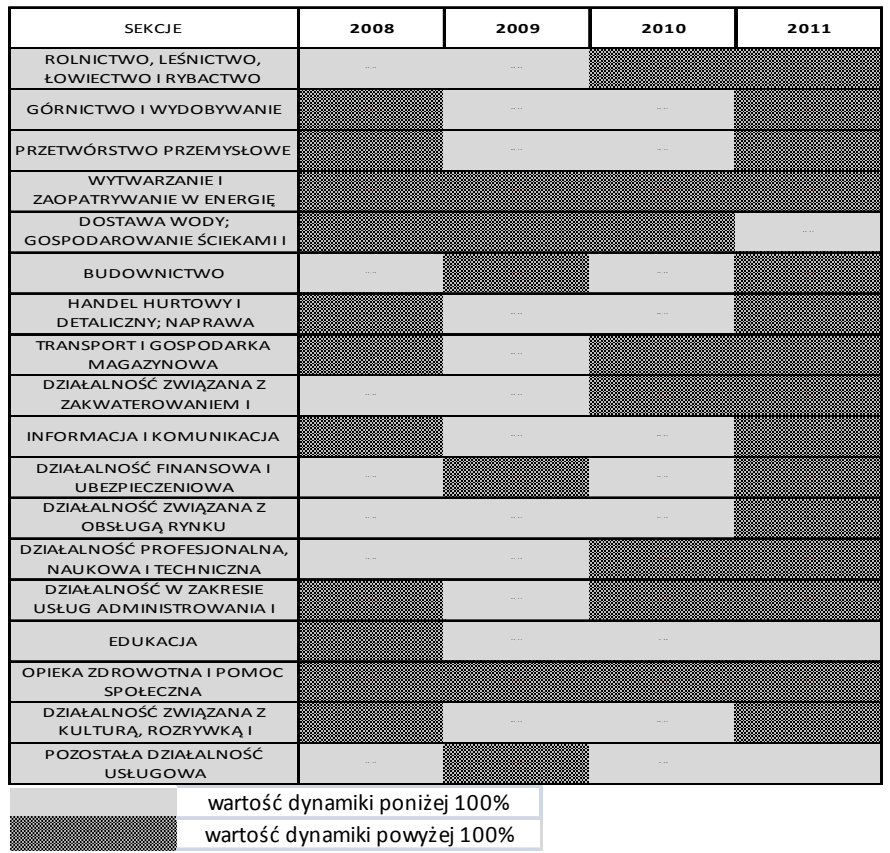

Mapa 6. Mapa dynamiki nakładów inwestycyjnych przedsiębiorstw zatrudniających powyżej 249 osób według sekcji (PKD 2007) w Polsce w latach 2007-2011

Źródło: opracowanie własne na podstawie danych zawartych w tab. 6 . 
Zmiany wartości dynamiki przychodów ze sprzedaży w latach 1998-2007 zaprezentowane $w$ graficznej postaci na mapach 7 i 8 wskazują na coroczny wzrost ich wartości jedynie w przedsiębiorstwach zajmujących się transportem, gospodarką magazynową i łącznością. W latach 2001-2003 w przedsiębiorstwach budowlanych odnotowano zmniejszanie się wartości przychodów ze sprzedaży, a w przedsiębiorstwach zajmujacych się górnictwem i kopalnictwem w 1999, 2002 i 2003 r. Również w przedsiębiorstwach przetwórstwa przemysłowego w 2001 r. zaobserwowano zmniejszenie. W latach 2007-2011 (mapa 8) coroczny wzrost wartości osiaganych przychodów ze sprzedaży odnotowano w przedsiębiorstwach zajmujących się wytwarzaniem i zaopatrywaniem w energię elektryczna, gaz, parę wodną, gorącą wodę i powietrze do układów klimatyzacyjnych, dostawą wody, gospodarowaniem ściekami i odpadami oraz działalnością związaną z rekultywacją, budownictwem oraz działalnością w zakresie usług administrowania i działalnością wspierająca. Podobnie, jak w przypadku liczby pracujących i nakładów inwestycyjnych w 2009 r. zaobserwowano zmniejszenie wartości osiaganych przychodów ze sprzedaż w większości sekcji PKD.

\begin{tabular}{|c|c|c|c|c|c|c|c|c|c|}
\hline SEKCJE & 1999 & 2000 & 2001 & 2002 & 2003 & 2004 & 2005 & 2006 & 2007 \\
\hline \multicolumn{10}{|l|}{$\begin{array}{l}\text { ROLNICTWO, ŁOWIECTWOI } \\
\text { LEŚNICTWO }\end{array}$} \\
\hline \multicolumn{10}{|l|}{ RYBOtÓWSTWO I RYBACTWO } \\
\hline \multicolumn{10}{|l|}{ GÓRNICTWO I KOPALNICTWO } \\
\hline \multicolumn{10}{|l|}{ PRZETWÓRSTWO PRZEMYStOWE } \\
\hline \multicolumn{10}{|l|}{$\begin{array}{l}\text { WYTWARZANIE IZAOPATRYWANIE } \\
\text { W ENERGIĘ ELEKTRYCZNA, GAZ, }\end{array}$} \\
\hline \multicolumn{10}{|l|}{ BUDOWNICTWO } \\
\hline \multicolumn{10}{|l|}{$\begin{array}{l}\text { HANDEL HURTOWYI DETALLCZNY; } \\
\text { NAPRAWA POJAZDÓW }\end{array}$} \\
\hline \multicolumn{10}{|l|}{ HOTELE I RESTAURACJE } \\
\hline \multicolumn{10}{|l|}{$\begin{array}{l}\text { TRANSPORT, GOSPODARKA } \\
\text { MAGAZYNOWAI EACZZNOŚĆ }\end{array}$} \\
\hline \multicolumn{10}{|l|}{ POŚREDNICTWO FINANSOWE } \\
\hline \multicolumn{10}{|l|}{$\begin{array}{l}\text { OBStUGA NIERUCHOMOŚCI, } \\
\text { WYNAJEM, NAUKA I UStUGI }\end{array}$} \\
\hline \multicolumn{10}{|l|}{ EDUKACJA } \\
\hline \multicolumn{10}{|l|}{$\begin{array}{l}\text { OCHRONA ZDROWIA I OPIEKA } \\
\text { SPOLECZNA }\end{array}$} \\
\hline $\begin{array}{l}\text { POZOSTALA DZIAtALNOŚĆ } \\
\text { UStUGOWA KOMUNALNA, }\end{array}$ & & & & & & & & & \\
\hline wa & dyna & oniż & $0 \%$ & & & & & & \\
\hline war & ć dyna & powyż & $0 \%$ & & & & & & \\
\hline
\end{tabular}

Mapa 7. Mapa dynamiki przychodów ze sprzedaży przedsiębiorstw zatrudniających powyżej 249 osób według sekcji (PKD 2004) w Polsce w latach 1998-2007

Źródło: opracowanie własne na podstawie danych zawartych w tab. 7. 


\begin{tabular}{|c|c|c|c|c|}
\hline SEKCJE & 2008 & 2009 & 2010 & 2011 \\
\hline \multicolumn{5}{|l|}{$\begin{array}{l}\text { ROLNICTWO, LEŚNICTWO, } \\
\text { ŁOWIECTWO I RYBACTWO }\end{array}$} \\
\hline \multicolumn{5}{|l|}{ GÓRNICTWO I WYDOBYWANIE } \\
\hline \multicolumn{5}{|l|}{ PRZETWÓRSTWO PRZEMYStOWE } \\
\hline \multicolumn{5}{|l|}{$\begin{array}{c}\text { WYTWARZANIE I ZAOPATRYWANIE } \\
\text { W ENERGIĘ ELEKTRYCZNA, GAZ, }\end{array}$} \\
\hline \multicolumn{5}{|l|}{$\begin{array}{c}\text { DOSTAWA WODY; } \\
\text { GOSPODAROWANIE ŚCIEKAMI I }\end{array}$} \\
\hline \multicolumn{5}{|l|}{ BUDOWNICTWO } \\
\hline \multicolumn{5}{|l|}{$\begin{array}{c}\text { HANDEL HURTOWY I DETALICZNY; } \\
\text { NAPRAWA POJAZDÓW }\end{array}$} \\
\hline \multicolumn{5}{|l|}{$\begin{array}{l}\text { TRANSPORT I GOSPODARKA } \\
\text { MAGAZYNOWA }\end{array}$} \\
\hline \multicolumn{5}{|l|}{$\begin{array}{l}\text { DZIAtALNOŚĆ ZWIAZANA Z } \\
\text { ZAKWATEROWANIEM I }\end{array}$} \\
\hline \multicolumn{5}{|l|}{ INFORMACJA I KOMUNIKACJA } \\
\hline \multicolumn{5}{|l|}{$\begin{array}{l}\text { DZIAtALNOŚĆ FINANSOWA I } \\
\text { UBEZPIECZENIOWA }\end{array}$} \\
\hline \multicolumn{5}{|l|}{$\begin{array}{l}\text { DZIAtALNOŚĆ ZWIAZANA Z } \\
\text { OBStUGA RYNKU }\end{array}$} \\
\hline \multicolumn{5}{|l|}{$\begin{array}{c}\text { DZIAtALNOŚĆ PROFESJONALNA, } \\
\text { NAUKOWA I TECHNICZNA } \\
\end{array}$} \\
\hline \multicolumn{5}{|l|}{$\begin{array}{c}\text { DZIAtALNOŚĆ W ZAKRESIE UStUG } \\
\text { ADMINISTROWANIA I } \\
\end{array}$} \\
\hline \multicolumn{5}{|l|}{ EDUKACJA } \\
\hline \multicolumn{5}{|l|}{$\begin{array}{l}\text { OPIEKA ZDROWOTNA I POMOC } \\
\text { SPOŁECZNA }\end{array}$} \\
\hline \multicolumn{5}{|l|}{$\begin{array}{l}\text { DZIAEALNOŚĆ ZWIAZANA Z } \\
\text { KULTURA, ROZRYWKA I }\end{array}$} \\
\hline \multicolumn{5}{|l|}{$\begin{array}{c}\text { POZOSTAtA DZIAtALNOŚĆ } \\
\text { UStUGOWA }\end{array}$} \\
\hline wartość dyn & oniże & & & \\
\hline wartość dyn & powyż & & & \\
\hline
\end{tabular}

Mapa 8. Mapa dynamiki przychodów ze sprzedaży przedsiębiorstw zatrudniających powyżej 249 osób według sekcji (PKD 2007) w Polsce w latach 2007-2011

Źródło: opracowanie własne na podstawie danych zawartych w tab. 8 .

\section{PODSUMOWANIE}

Podsumowując wyniki analizy i oceny zmian liczby oraz dynamiki działalności gospodarczej dużych przedsiębiorstw w Polsce latach 1998-2011 można stwierdzić, że:

- w analizowanym okresie czasu liczba osób pracujących w nich zmieniła się nieznacznie,

- nie można wskazać przedsiębiorstw, które w całym analizowanym okresie cechowały się wzrostem wybranych mierników (działalności gospodarczej),

- w latach 2001-2003 oraz w 2009 r. odnotowano zmniejszenie liczby pracujących, wartości nakładów inwestycyjnych dużych przedsiębiorstw,

- nie zaobserwowano zależności zmian pomiędzy analizowanymi miernikami,

- w całym okresie objętym analizą zaobserwowano tendencję wzrostu w dynamice nakładów inwestycyjnych i liczby pracujących,

- zaobserwowano od 2009 r. zmniejszanie wartości nakładów inwestycyjnych i liczby pracujących w przedsiębiorstwach zajmujących się budownictwem, 
- wartość dynamiki powyżej 100 praktycznie w całym analizowanym okresie $\mathrm{w}$ przedsiębiorstwach zajmujących się wytwarzaniem i zaopatrywaniem w energię elektryczną, gaz, gorącą wodę i parę wodną,

- zaobserwowane zmiany dynamiki analizowanych mierników wskazywać mogą na niską intensywność przekształceń ich struktury,

- brak możliwości wskazania jednoznacznych tendencji zmian.

Interesujące byłoby dokonanie szczegółowej analizy zmian strukturalnych dużych pomiotów oraz porównanie zaobserwowanych zmian działalności gospodarczej dużych przedsiębiorstw w Polsce do grupy małych i średnich podmiotów. Wymaga to jednak bardziej szczegółowej analizy i oceny zmian wielkości i struktury działalności gospodarczej dużych przedsiębiorstw, w której użyte powinny być także inne poza tymi, które wykorzystano w pracy mierniki działalności gospodarczej dużych przedsiębiorstw.

\section{BIBLIOGRAFIA}

Cho mąt ow ski S., Rozwój przemystu w świecie, Akademia Ekonomiczna w Krakowie, Kraków 1986.

Chomątowski S. (red.), Dynamika i kierunki zmian wielkości i struktury sektora przedsiębiorstw $w$ Polsce $w$ latach 1990-2005, Uniwersytet Ekonomiczny w Krakowie - Fundacja Uniwersytety Ekonomicznego w Krakowie, Kraków 2010.

Krze mińs ki P., Zmiany liczby i struktury jednostek gospodarczych w Polsce w latach 19912007, [w:] Prace z zakresu ekonomiki i organizacji przedsiębiorstw, ZN UEK, Nr 836, Uniwersytet Ekonomiczny w Krakowie, Kraków 2010, s. 179-194.

Kuznets S., Wzrost gospodarczy narodów, produkt i struktura produkcji, PWN, Warszawa 1976.

W in i ars ki B., Polityka gospodarcza, Wydawnictwo Naukowe PWN, Warszawa, 2010.

Konrad Kolegowicz

\section{TRENDS AND DIRECTIONS OF CHANGES IN THE BUSINESS OF LARGE ENTERPRISES IN POLAND IN THE YEARS 1998-2011}

This paper presents the results of the research in the dynamics of changes in the economic activities of large enterprises in Poland. On that base is done the attempt of the assess trends and changes in the number of employees, assets, capital expenditures and revenues for the realization of the overall objectives of structural changes in the economy. Results of the research of dynamics of the analyzed measures do not allow for a clear indication of the direction of change. The results show the need for a detailed study of the structural changes and the level of concentration and deconcentration of large enterprises in Poland.

Key words: large enterprises, trends of development, number of employees, fixed assets, investment outlays, total revenue. 